\title{
GENDER AND EXPLETIVES AS DISCOURSE MARKERS: SOME USES OF JODER IN YOUNG WOMEN'S INTERACTIONS IN SPANISH AND GALICIAN
}

\author{
EL GÉNERO Y LOS TACOS COMO MARCADORES \\ DISCURSIVOS: ALGUNOS USOS DE JODER EN \\ INTERACCIONES DE MUJERES JÓVENES EN ESPAÑOL \\ Y GALLEGO
}

Virginia ACUÑA FERREIRA

\section{Author / Autora:}

Virginia Acuña Ferreira

Universidad de Zaragoza

Zaragoza, Spain

Virginia@unizar.es

https://orcid.org/0000-0001-6845-4242

Submitted / Recibido: 20/10/2020

Accepted / Aceptado: 09/04/2021

To cite this article / Para citar este artículo: Acuña Ferreira, V. (2021). Gender and expletives as discourse markers: Some uses of joder in young women's interactions in Spanish and Galician. Feminismo/s, 38, 53-83. Women, Sexual Identity and Language [Monographic dossier]. I. Balteiro (Coord.). https://doi.org/10.14198/ fem.2021.38.03

Licence / Licencia:

This work is licensed under a Creative Commons Attribution 4.0 International.

\section{(c) (1)}

(C) Virginia Acuña Ferreira

\begin{abstract}
This paper approaches young women's speaking style by analysing the ways in which the interjection joder is employed in interactions in Spanish and Galician among young females. The analysis identifies several uses of this form at the interactional and discursive level: reinforcement of speech acts, marker of disagreement, marker of complaints, expression of minimal emotional assessments, correcting and stalling. It is concluded that joder has developed multiple functions in interaction as a discursive marker, in contrast to arguments against the inclusion of interjections in this pragmatic category. The findings also suggest that this expletive fulfils a sociolinguistic function as a marker of 'young femininities', since it demonstrates how it has been integrated into young women's speaking style, in contrast to traditional gender rules and broader descriptions of 'women's talk' in Language and Gender studies.
\end{abstract}


Gender and expletives as discourse markers: Some uses of joder in young women's interactions in Spanish and Galician

Keywords: Gender; Expletives; Joder; Discourse marker; Young women's talk; Young femininities.

\section{Resumen}

Este artículo aborda el estilo de habla de las mujeres jóvenes analizando las formas en que se emplea la interjección joder en interacciones en español y gallego entre veinteañeras. El análisis identifica varios usos de esta forma en el nivel interaccional y discursivo: refuerzo de actos de habla, marcador de desacuerdo, marcador de quejas, expresión de valoraciones emocionales mínimas, corrección y relleno. Se concluye que joder ha desarrollado múltiples funciones en la interacción como un marcador discursivo, frente a los argumentos en contra de la inclusión de las interjecciones en esta categoría pragmática. Los resultados sugieren además que este taco cumple una función sociolingüística como marcador de 'feminidades juveniles', ya que demuestran cómo se ha integrado en el estilo de habla de mujeres jóvenes, en contraste con los mandatos tradicionales de género y las descripciones más amplias del 'habla de las mujeres' en los estudios sobre Lengua y Género.

Palabras clave: género; tacos; joder; marcador discursivo; habla de mujeres jóvenes; feminidades juveniles.

\section{INTRODUCTION}

This paper approaches young women's speaking style by analysing how the Spanish word joder is used in interactions among female speakers in their early 20's. These interactions are produced in Spanish and Galician, as the participants are mostly from Galicia (Spain) ${ }^{1}$. Specifically, the study focuses on the discursive and interactional functions of joder in its grammatically invariable form as an expletive or 'vulgar interjection' (RAE \& ASALE, 2014). In Spanish grammars, interjections of this type are only attributed an 'expressive' function: the speaker's communication of feelings (RAE \& ASALE, 2010, pp. 630-632). However, some authors have defended that interjections can fulfil multiple functions in interaction, acting as 'discourse markers' (Blas

1. While joder is a Spanish word, which is translated into Galician as foder, it is also commonly used by speakers of Galician as an interjection. From a pragmatic viewpoint, this interjection can be thus considered an element of informal speaking styles, whether in Spanish or Galician.

Feminismo/s 38, July 2021, 53-83 
Gender and expletives as discourse markers: Some uses of joder in young women's interactions in Spanish and Galician

Arroyo, 1995) or 'discourse particles' (Drescher, 1997). According to Blas Arroyo (1995, p. 86), discourse markers are «piezas importantes en los procesos de construcción conjunta de la interacción [...] y también contribuirían al añadido de matices diversos de significación emotiva e interpersonal ${ }^{2}$. While he argues for the inclusion of at least some interjections in this category, other researchers generally exclude them, arguing that they only serve the discursive function that corresponds to their grammatical class, such as the expression of feelings (Borreguero Zuloaga, 2015). This assumption could explain that corpus-based research on Spanish and English colloquial conversation has not paid much attention to expletives as discourse markers (Briz, 1998; Briz et al., 2008; Stenström, 2014) or that approaches to them are taken from a predominantly quantitative perspective (Murphy, 2009; Stenström, 2006, 2014), which results in an oversimplified picture of their functional properties. In this way, one of the aims of this paper is to provide a more in-depth analysis of how joder is employed in colloquial conversation to demonstrate its multifunctionality as a discourse marker.

A second aim of this paper is to apply a gender perspective to the analysis of this form in young women's friendly interactions, taking as a premise that expletives are stereotypically linked to men and masculinity, as sociocultural restrictions on their use have been traditionally much more severe for women in different languages and cultures (Coates, 2004; Lakoff, 1975/2004; Lozano Domingo, 1995). Because of these gender-based restrictions and their association with 'verbal aggressiveness', expletives can be considered as part of the vernacular culture that entails 'covert prestige' (Trudgill, 1983) for men, as argued by Lozano-Domingo (1995, p. 125). Such social constructions, however, do not exclude the possibility that women also employ these words because of the influence of other social factors, such as age or class, the communicative situation and/or a desire to challenge them. Taking a social-constructionist conceptualisation of gender (Acuña, 2009, 2011a; Holmes \& King, 2017; Mills, 2003; Pichler, 2015), this paper will focus on these latter possibilities. More specifically, I intend to call attention to the

2. Blas Arroyo (1995, p. 86, my translation): «important pieces in the processes of joint construction of the interaction [...] and would also contribute to the addition of various nuances of emotional and interpersonal significance».

Feminismo/s 38, July 2021, 53-83 
Gender and expletives as discourse markers: Some uses of joder in young women's interactions in Spanish and Galician

multiple functions that joder can acquire in talk among young women from middle-class backgrounds, contributing to displaying a speaking style that notably contrasts with general characterisations of 'women's talk' in previous Language and Gender research. The following section provides an overview of this research, in which discourse markers and expletives have been studied separately, in line with the general trend that I have already pointed out from the beginning.

\section{GENDER, DISCOURSE MARKERS AND EXPLETIVES}

An early reference to women's avoidance of swearing was made by Jespersen (1922, p. 246): «Among the things women object to in language must be specially mentioned anything that smacks of swearing». From a feminist perspective, this matter was originally addressed by Robin Lakoff (1975/2004) in Language and woman's place. Lakoff critically argued that women are educated to be gentle and polite so that they learn to employ a 'powerless' speaking style, by which they are later perceived as insecure and unable to express themselves forcefully. This 'women's language' is based, for example, on the use of 'weak expletives' like goodness or oh fudge and the employment of tag questions to avoid strong statements, as in The way prices are rising is horrendous, isn't it? (Lakoff, 1975/2004, p. 49). Such arguments have given rise to many studies on women's and men's use of tag questions and other English discursive particles like I think, sort of, kind of or probably (see Aries, 1996, for a discussion). Drawing on the analysis of spoken discourse corpora and the politeness theory proposed by Brown \& Levinson (1987), some of these studies concluded, from a more positive viewpoint, that such forms are multifunctional and that women tend to employ them as both positive and negative politeness strategies (Cameron et al., 1988; Coates, 1996; Holmes, 1995) to foster interaction, to avoid strong statements so as not to impose own's opinions and to keep contact with the interlocutor ${ }^{3}$. Recent research

3. Brown \& Levinson (1987) elaborated a politeness theory based on Goffman's (1967) notion of 'face'. These authors distinguished between a negative and a positive face, which were defined as «the desire to be unimpeded in one's actions (negative face), and the desire (in some respects) to be approved of (positive face)» (1987, p. 13). From this perspective, positive politeness strategies are those oriented to protect the speaker's

Feminismo/s 38, July 2021, 53-83 
Gender and expletives as discourse markers: Some uses of joder in young women's interactions in Spanish and Galician

based on spoken discourse corpora in Spanish (Albelda et al., 2020) provides similar results in relation to geographic areas like Madrid, where women showed a greater tendency than men to use linguistic and paralinguistic devices to avoid imposing on others by softening assertions. However, the spoken discourse data obtained in Valencia, Las Palmas de Gran Canaria and Santiago de Chile indicated that this gender difference was reversed or that it did not exist in this respect.

Lakoff's (1975/2004) hypotheses also stimulated a body of research on gender and expletives that was initially based on questionnaires. Earlier studies that emerged in the USA revealed that single, younger and feminist women reported using expletives more than married, older and non-feminist women (Bailey \& Timm, 1976; Oliver $\&$ Rubin, 1975) or did not find a difference in comparison to men (Staley, 1978). Later research on other countries re-emphasises women's heterogeneity, noting that British women from the lower working class regularly use these kinds of words (Hughes, 1992), or a lack of gender differentiation among teenagers of an English-speaking school in South Africa (De Klerk, 1992, 1997). Chun (1991, cited in Lozano Domingo, 1995, pp. 124-125) carried out a study among Spanish speakers from Madrid, which found that men and young people without higher education used most of the lexical items under study to a greater extent than women and young undergraduate students, although joder was one of the expletives with a more balanced frequency of use between women and men.

More recently, studies based on the analysis of spoken interactions have stressed the links between masculinity and the use of expletives, insults and generally taboo words, as well as their special significance in men's talk as forms of camaraderie, in line with the classical study by Labov (1972) on ritual insults among male teenagers from New York. See, for example, the studies by Pujolar (1997) on two youth gangs from Barcelona, Zimmermann (2002, 2005) on young men from Spain, Mexico and Uruguay, or Martínez Lara (2009) on students from the Universidad Central de Venezuela. Coates (1996, 2003) analyses friendly conversations among British speakers and

and/or the recipient's positive face, for example, by seeking agreement, while negative politeness strategies intend to avoid impositions on the speaker and/or the recipient, for example, by avoiding promises and strong assertions.

Feminismo/s 38, July 2021, 53-83 
remarks on the importance of taboo words as devices to express solidarity and to reinforce hegemonic masculinity in all-male interactions, while this type of language is much less frequent in all-female data (Coates, 2003). The magnitude of this gender difference is illustrated by highlighting the case of fuck, which is usually taken as the English equivalent to joder: «the word fuck and words deriving from it (fucking, fucked, fucker, etc.) appear 72 times in the stories in the all-male sub-corpus, 12 times in the mixed sub-corpus, and not at all in the all-female sub-corpus» (2003, p. 45). My previous research on third-party complaints in interactions in Spanish and Galician among friends and relatives (Acuña, 2002/2003, 2004, 2011a, 2011b) found that expletives were not only employed by male participants but played a prominent role in their speaking style, making their indignation displays especially 'aggressive'.

While it seems that gender continues to make a difference in the use of expletives, even among young people, other recent studies on interactions in English and Spanish that focus on teenagers or include young speakers point to the growing importance of expletives and taboo words in girls' talk, paying special attention to joder and the English fuck. Stenström (2006) compares the occurrences of taboo words in two subsets of The Bergen Corpus of London Teenage Language (COLT) and the Corpus de Lenguaje Adolescente de Madrid (COLAm), which are constituted by colloquial conversations among teenagers from London and Madrid, respectively. This comparative analysis is restricted to interactions among girls, in which fuck and joder were the most frequent taboo words. Regarding gender differences, Stenström refers to a previous research on the COLT (Stenström et al., 2002), in which fuck/ed/ing «occurred more than twice as often in boys' as in girls' speech» (Stenström, 2006, p. 122). However, in a later study, Stenström (2014) emphasises that gender differences are diminishing in terms of frequency: «the girls are catching up with the boys when it comes to frequency, while there is still a difference in the type of words, in that the rudest words are used by boys» (2014, p. 11).

Murphy (2009) provides a quantitative and qualitative analysis of fuck (including its variations fucking, fucked and fucker) in Irish English, relying on data from the Corpus of Age and Gender differentiated spoken Irish English (CAG-IE), which allows comparisons to be made according to gender and 
three age groups: 20 s, 40 s and 70s/80s. The analysis found that the highest number of occurrences of fuck and its variations corresponded to males in their 20s (111), which was more than double the number for females in this age group (51). Male adults of the 40s group also used these forms much more than their female counterparts (65/18), while the oldest male and female groups did not use it at all. The qualitative analysis is focused on fucking as the most common form, which is said to fulfil two functions: as an 'amplifier' to express emotions and attitudes, and as a premodifying intensifier. Generally, Murphy stresses the more frequent use of fuck and its variations in the male data as a marker of masculinity, but it also seems worthy of mention that the number of occurrences of these forms in the female 20s group is close to the male 40s data (65/51).

In sum, research based on the analysis of interactions confirms that men generally use expletives and taboo words more than women, even in the case of youths, according to gender-based traditional rules. However, as men's employment of this type of language is often emphasised as a marker of masculinity, the relatively high frequency of use among young female speakers that has also been found equally deserves due attention, as it suggests a possible sociolinguistic change in process and/or underlines the contextual variability of gender. In addition to this, more qualitative approaches, which allow us to observe in detail how expletives are used and can function in interaction, are lacking. Since many studies on expletives tend to prioritise quantification, they reduce the functional properties of these kinds of words, reaching results that they cannot explain. For example, in her study of taboo words in Spanish and English conversation among female teenagers, Stenström (2006) only differentiates on a discourse level between a phatic function of taboo words and a non-phatic function, "where the taboo words only reflect the speaker's moods» (2006, p. 129). In her conclusions, she comments: «it came as a surprise that the Spanish word joder occurred almost as frequently as English 'fuck', despite the fact that 'fuck' not only appears in more forms but is also used for more [grammatical] functions» (2006, p. 135). The reasons for this balance could have much to do with the fact that joder is used for more discursive and interactional functions than those differentiated in this study, in contrast to its grammatical invariability, as I aim to demonstrate in the following section.

Feminismo/s 38, July 2021, 53-83 
Gender and expletives as discourse markers: Some uses of joder in young women's interactions in Spanish and Galician

\section{DATA AND ANALYSIS}

In this section I will analyse conversational data that were taken from the Corpus of Galician/Spanish Bilingual Speech of the University of Vigo (Corpus de Fala Bilingüe Galego/Castelán, abbreviated as CoFaBil; Rodríguez Yáñez \& Casares, 2002/2003), which was collected in Galicia (Spain) through participant observation with a hidden microphone. Overall, this corpus comprises around 250 hours of audio-recorded material. The data collection was made from an ethnographical perspective, that is, the main interest was to obtain naturally occurring interactions:

a high proportion of the recordings were made at the home of the participants (chats over coffee, family meals, etc.) besides conversations between neighbours, housewives, students, returned emigrants, interactions between infants and carers, interactions in groups of friends (male, female and mixed), with strangers in the street, telephone conversations and also in all types of public settings: urban and village markets, groceries, department stores, chemist's shops, cafeterias, bars, hairdresser's, etc. (Rodríguez Yáñez \& Casares, 2002-2003, p. 362).

The CoFaBil was a part of research projects in which the author herself participated as a researcher. Specifically, I contributed to the data collection, acting as a participant observer in the natural interactions of my own groups of friends, relatives, and acquaintances (Acuña, 2009, 2011a) ${ }^{4}$. I also collaborated in the data transcription, employing a system of conventions that is adapted from Álvarez Cáccamo (1990). As is usual in the transcription of data by conversation analysts, these conventions pay close attention to the facts concerning the turn-taking system, the most relevant prosodic phenomena, as well as to aspects of non-verbal communication that can be perceived in audio recordings, such as claps or whistles. Unlike other systems, however, each line of the transcription tends to correspond to a semantic-syntactic or subintonation unit as it coincides with an 'intentional

4. All members of these groups were informed of the research that was being conducted and gave consent for some of their conversations to be audio recorded. To guarantee spontaneity and naturalness, I opted not to notify participants of the recording at the time of it but once it had been made. Then, I requested their permission again to use it in research work (Tusón, 1997, pp. 98-99).

Feminismo/s 38, July 2021, 53-83 
movement' (Rodríguez Yáñez, 2007), which is defined as the minimal unit in the conversational process. In this way, ellipsis, segmented constructions or self-repairs are considered to be micromoments of the discursive construction that can be better visualised in the transcript (Rodríguez Yáñez, 2007, p. 44). The Appendix provides an abbreviated version of these conventions, in which I have only included the symbols that appear in the conversational extracts to be analysed here.

The present study is based on five colloquial conversations among friends from the CoFaBil that were audio recorded in the late 1990s or early 2000s, as is the case of the Corpus de Lenguaje Adolescente de Madrid (COLAm) (Stenström, 2014, p. 2). The participants are all female friends in their early 20s, mostly undergraduate students, middle class and speakers of Spanish and Galician. The selection of these conversations was made because they constitute naturally occurring talk among young women and because of my previous work on them to address different issues, such as the construction of femininities (Acuña, 2009, 2012, 2017a, 2017b), complaints (Acuña, 2011a), humour (Acuña, 2012) and storytelling in conversation (Acuña, 2020). In doing this previous work, I realised that joder generally played an important role in these interactions and that it was used in different ways, so I initiated an analysis focused on this form, observing each of its occurrences in the five interactions to assign it a communicative function. I noted the position of joder in the turn, which was conceptualised as «a communicative unit in speech that is both communicatively and pragmatically complete» (Ronald $\&$ McCarthy, 2006, p. 928). Also, I paid attention to prosodic realisation, the communicative purpose and the interpersonal and/or textual level on which joder operates (Stenström, 2014) as well as to the type of conversational sequence or «more global communicative patterns» (Drescher, 1997, p. 239) in which it was used.

In this way, I came to categorise six uses and functions of the interjection joder, which are addressed in the following subsections. There were cases that remained unclassified to which I plan to return in future studies. 


\subsection{Reinforcing Speech Acts}

One of the most frequent occurrences of joder in the data is found in turn-final positions as the 'closing marker' (Drescher, 1997, p. 239) of a statement, directive or request, serving to strengthen the illocutionary force of these speech acts. Following Briz (1998, pp. 128-135), these uses would be included in the category of 'pragmatic modifiers' that intensify the speaker's attitude and are dialogically oriented to emphasise agreement or disagreement. For example, in (1), joder is used by Raquel to strengthen a directive and to emphasise agreement with previous turns of Silvia, who asked for a cigarette and expressed a desire to smoke after a long time without having done so. The performance of said directive by using the verb envenenar ('to poison') and its final reinforcement by means of joder can also be attributed a humorous intention (lines 711-712):

(1)

$\begin{array}{lll}695 & \text { Silvia } & \text { Lucía } \rightarrow \\ 696 & & \text { me das un Chesterfield? } \\ 697 & \text { Lucía } & \text { non teño } \rightarrow \\ 698 & & \text { vou a comprar } \rightarrow \\ 699 & & \text { ah bueno } \rightarrow \\ 700 & \text { Silvia } & {[(\mathrm{xx})]} \\ 701 & & {[\text { non }] \rightarrow} \\ 702 & \text { Lucía } & \text { vou a cambiar } \rightarrow \\ 703 & & \text { que non é o mesmo } \rightarrow \\ 704 & & . . \\ 705 & & \text { tengo yo } \rightarrow \\ 706 & & . . \\ 707 & & \\ 708 & \text { Begoña } & \\ 709 & & <3> \\ 710 & & \text { hace mucho tiempo que no fumo } \rightarrow \\ 711 & & \text {.. } \\ & & \text { Rues fuma } \rightarrow\end{array}$

Feminismo/s 38, July 2021, 53-83 
Gender and expletives as discourse markers: Some uses of joder in young women's interactions in Spanish and Galician

712 envenena tu cuerpo joder $\rightarrow=$

713 Silvia $=$ a tu salud $\uparrow$

714 $<5>$

Extract (2) illustrates several uses of joder in a segment of direct reported speech. The speaker, Natalia, is staging a discussion she held with her cousin about the sexual problems the latter had with her boyfriend. Natalia tries to convince her cousin that she should leave this relationship (2):

Natalia =y mi prima iba de samaritana $\uparrow$

$81 \rightarrow$

en plan $\rightarrow$

$82 \rightarrow$

joder $\uparrow$

83

tiene un problema $\rightarrow$

84

y yo $\rightarrow$

vale $\uparrow$

85

luisa $\rightarrow$

86

tiene un problema $\rightarrow$

87

pero es que si no lo quieres aceptar $\uparrow$

88

no lo quiere ÉL aceptar $\uparrow$

89

$90 \rightarrow$

$\{[a c]$ no vas a estar toda la vida con un tío que no fo:lla\} $\uparrow$

$91 \quad \rightarrow \quad$ joder $\rightarrow<$ riéndose $>$

92

sabes? $=$

93

(X) = he he he =

$94 \rightarrow$

Natalia $=$ ES QUE ES ASÍ $\uparrow$

95

joder $\rightarrow=$

96

Begoña es que es así $\downarrow$

97

Natalia describes her cousin's attitude towards her own boyfriend as that of a samaritana ('samaritan', line 79) and then employs the marker en plan ('like', 
line 80) to frame a direct quotation of this character (Stenström, 2014, pp. 93-94). This quotation serves as a 'demonstration' (Clark \& Gerrig, 1990) of her cousin's sympathetic attitude, as she defends her boyfriend, arguing that he has a problem (lines 81-82). Note that the quoted character employs joder in turn-initial position as a marker of her disagreement with Natalia, another function that is addressed specifically in the following subsection. The reporting continues with Natalia's response, which is constituted as an 'agreement-plus-disagreement turn shape' (Pomerantz, 1984, p. 72): it is prefaced by agreement components, including vale ('okay', lines 83-86) as a marker of concession (Briz, 1998, p. 182), followed by pero ('but') to articulate opposition (lines 87-88).

After a micropause (line 89), Natalia claims the impossibility of the relationship, making a statement that is reinforced by using joder in the turn-final position (lines 90-91). She then uses sabes? ('you know', line 92) as a 'trigger' (Stenström, 2014, p. 58), inviting the participants to produce an understanding or agreement response with this perspective. One participant displays such affiliation by laughing (line 93), as Natalia did in the previous turns (line 91). Natalia reasserts her point of view, increasing the volume and using joder again as the closing marker of a statement (lines 94-95). This prosodic emphasis and the use of joder also function here as triggers, inviting agreement responses. Begoña provides such a response in the following turn (line 96) through a repetition of Natalia's previous statement.

\subsection{Marking Disagreement}

In her analysis of the ways in which agreement and disagreement turns are shaped in conversation, Pomerantz (1984, p. 72) notes that disagreement, as a dispreferred action, tends to be delayed or prefaced in some ways, for example, by means of vocalisations such as uhs or particles like wells, «thus displaying reluctancy or discomfort» (1984, p. 72). This corpus of young women's interactions provides some instances in which joder functions similarly as a disagreement marker in the initial position of a turn that is clearly reactive to the previous ones as a disagreement response, thus serving an interpersonal function. These kinds of turns have been found in sequences of discussion or in segments of direct reported speech in storytelling sequences

Feminismo/s 38, July 2021, 53-83 
that stage such conversational activity, as we saw in extract (2) regarding the first occurrence of joder.

In comparison to the use of well and the vocalisations described by Pomerantz (1984), the use of joder as a disagreement marker may be surprising, from the perspective of politeness, because it is linked to strongly negative stances, so this does not seem the best way to introduce a non-preferred reaction, as it is disagreement. The examples of this use seem then to reinforce the normalisation of this expletive among the speakers, while there are cases in which it is followed by the vocative tio/a as a hedge or mitigator to emphasise social bonds between the interlocutors when performing face threatening acts (FTA) (De Latte \& Enghels, 2019; see also Edeso Natalías, $2005)^{5}$. Extract (3) provides an example of this use of joder followed by the vocative tía in expressing disagreement. Eva is talking about a boy with whom she has recently started an intimate friendship, praising the fact that he gets along with his ex-girlfriends. There is a second use of joder in this extract that fulfils a different function:

(3)

52 Eva detalles que me molan $\rightarrow$

53 detalles del tipo $\rightarrow$

$54 \quad$ por ejemplo $\rightarrow$

55 que se lleva bien con sus ex novias $\uparrow$

$56 \quad(\mathrm{xx})$

57 porque $(\mathrm{xx}) \uparrow$

58 porque si se lleva bien con ellas $\uparrow$

59

60

61

62

cuando yo sea $\rightarrow$

también $\rightarrow$

una ex $\uparrow$

5. Brown \& Levinson (1987) define face threatening acts as «those acts that by their very nature run contrary to the face wants of the addressee and/or speaker» (1987, p. 65). Thus, disagreement is included by these authors as a threatening act for the interlocutor's positive face, as it is contrary to her/his desire for approval (see also footnote 3).

Feminismo/s 38, July 2021, 53-83 


\begin{tabular}{|c|c|c|c|}
\hline 63 & & & se llevará bien conmi:go $\rightarrow$ \\
\hline 64 & & & o sea \\
\hline 65 & & & dice mucho de una persona $\rightarrow$ \\
\hline 66 & $\rightarrow$ & Cris & (joder tía) cuando [tú seas una ex?] \\
\hline 67 & & Eva & [(entonces es)] \\
\hline 68 & $\rightarrow$ & & NO:: $\uparrow$ \\
\hline 69 & $\rightarrow$ & & PERO $\rightarrow$ \\
\hline 70 & $\rightarrow$ & & joder $\rightarrow$ \\
\hline 71 & & & $<0.5>$ \\
\hline 72 & & Cris & YA:: $\rightarrow$ \\
\hline 73 & & & QUE SÍ QUE SÍ $\rightarrow$ \\
\hline 74 & & Eva & $=$ SON DETA:LLES $\uparrow$ \\
\hline 75 & & & entiendes? \\
\hline
\end{tabular}

Eva explains her positive evaluation of the boy based on his good relationships with his ex-girlfriends, noting that she herself also will be an ex-girlfriend (lines 52-65). In overlap, Cris expresses disagreement by using joder tía ('fuck, girl', lines 66-67), followed by a questioning repeat (Pomerantz, 1984, pp. 71, 77) that displays strangeness and a critical attitude towards Eva's reasoning (line 66). While joder marks this disagreement, the vocative tía that follows serves as a politeness strategy to mitigate such FTA. Eva intends to respond to this implicit criticism by using no ('no') and pero ('but') with increased volume (lines 68-69), followed by joder (line 70), but then a micropause is produced (line 71) and Cris emphatically asserts her understanding of Eva's point of view (lines 72-73). In view of Eva's hesitation here in trying to reply to a disagreement with Cris (lines 68-70), the second use of joder by this participant in line 70 can be interpreted as a means to retain the turn and to take time to organise the discourse; that is, it can be interpreted as a 'filler' (Cortés, 1991) or 'stalling' device (Stenström, 2014, p. 92). This is another use of joder that will also be specifically addressed in another subsection.

In extract (4), joder is followed by pero ('but'), which also serves to mark, or rather to reinforce in this case, a disagreement response (Briz, 1998, pp. 182-185). Once more, the participants are talking about sexual/affective 
relationships with boys. Ana reproaches Begoña for not taking the opportunity to go with a boy to his friend's apartment:

Ana yo es que aún no entiendo $\uparrow$

cómo coño no te fuiste a la casa del::

Begoña eran las seis =

83

84

Ana = del amigo ése $=$

80

Begoña $=$ eran las siete de la mañana $\uparrow$

85

tía $\rightarrow$

86

87

88

89

90

91

92

Ana $\quad y$ ?

93

Natalia joder $\uparrow$

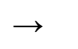

(xx)

94

Ana qué va $\rightarrow=$

Begoña $=$ no creo $\downarrow=$

Ana $=$ depende de cómo sigan las cosas $\rightarrow=$

Natalia $=$ ah ya $\rightarrow$

96 pero él $\uparrow$ muy ilusiona:do $\uparrow$

Ana joder $\rightarrow$

pero::

supongo que él $\uparrow$

se enrollará con tía::s $\rightarrow$

Begoña responds to Ana's reproachful question by arguing that it was too late (lines 76-81), using the vocative tía ('girl') to appeal to her understanding (lines 80-81), but Ana rejects this justification by asking iy? ('and', line 82). After a micropause (line 83), Natalia contributes to the discussion by using joder in turn-initial position, but what she says next is not intelligible (lines 84-85). This use of joder by Natalia seems to mark a disagreement response to her friends, as can be deduced from the following turns in which both 
Ana and Begoña disagree with this participant (lines 87-89), using no creo ('I don't think so') and qué va ('come on'), which is also described as a disagreement marker or 'objecting' device by Stenström (2014, pp. 77-80). The discussion continues, as Natalia introduces ah ya ('oh yes', lines 90-92) as a 'weak agreement component' (Pomerantz, 1984, p. 72), and next she uses pero ('but') to articulate disagreement. Ana disagrees with her (lines 93-99), using joder followed by pero (lines 93-94).

Thus, joder as a disagreement marker can be reinforced with pero, which also serves to mark the transition from a weak agreement to a disagreement (lines 90-92). Generally, this extract (4) provides a good illustration of the use of different disagreement markers in a discussion sequence.

\subsection{Marking Complaints}

The emotive meanings of joder as an interjection that expresses 'irritation' or 'annoyance' (RAE \& ASALE, 2014) make it useful as an 'affective key' (Ochs $\&$ Schieffelin, 1989) to contextualise the speaker's discourse into a complaint frame in such a way that it can be attributed a 'complaint marker' function in certain contexts. From a broad perspective, complaints have been defined «as expressive acts wherewith the speaker, or complainer or complainant, expresses a variety of negative feelings or emotions» (Padilla Cruz, 2019, p. 23) in relation to a situation and/or someone's behaviour. According to this definition, the use of joder as a complaint marker has been found in sequences in which the speaker is talking about someone's behaviour that made her feel bad or about something that is reported as an injustice. In these cases, joder appears in turn-initial position as an independent sustained or rising intonational unit, sometimes along with other prosodic features, such as vowel elongations or heightened volume. It seems to play a key role in marking the speaker's negative attitude to guide the listener in the interpretation of the discourse as a complaint to get empathy or support. Thus, these uses do not only fulfil an expressive function but also an interpersonal one.

In extract (5) joder is used in a segment of direct reported thought (DRT), previously analysed in Acuña (2020). Eva is telling a story about what happened one day when she was home alone, thinking sadly about the fact that her male friend had not phoned her, although he knew she had an exam

Feminismo/s 38, July 2021, 53-83 
the next day. These thoughts are staged as a complaint that is prefaced by joder with vowel elongation, followed by utterances that also present this prosodic feature (lines 970-972) to communicate sadness. Such a complaint is not only oriented to get sympathy and support but also more generally to emphasise the point of the story, as Eva finally receives a message from the boy that radically changes her mood (lines 974-980):

\begin{tabular}{|c|c|c|c|}
\hline 969 & $\rightarrow$ & Eva & y yo diciendo $\rightarrow$ \\
\hline 970 & $\rightarrow$ & & jode::r $\rightarrow<$ tono de tristeza $>$ \\
\hline 971 & $\rightarrow$ & & (xx) en todo el dí::a $\uparrow<$ tono de tristeza> \\
\hline 972 & $\rightarrow$ & & no me llamó:: $\uparrow<$ tono de tristeza> \\
\hline 973 & & Cris & = sí = \\
\hline 974 & & Eva & $=\mathrm{y}$ en eso $\uparrow$ \\
\hline 975 & & & pi pi $\uparrow$ \\
\hline 976 & & & mensaje $\rightarrow$ \\
\hline 977 & & & .. \\
\hline 978 & & & mucha suerte $\rightarrow$ \\
\hline 979 & & & un be:so $\downarrow$ \\
\hline 980 & & & he he he = \\
\hline 981 & & Cris & $=$ he he he \\
\hline 982 & & & qué ri:co = \\
\hline
\end{tabular}

Extract (6) similarly shows the use of joder in storytelling. Lara is saying that she looked at some shoes in a store, and then she negatively evaluates their price as too high. Following this, she complains about this price as an injustice, claiming that she could find the same shoes in other stores for half the price. This claim is prefaced by joder, which here constitutes a rising intonational unit that is close to the exclamatory intonation linked to interjections (lines 94-99): 
Gender and expletives as discourse markers: Some uses of joder in young women's interactions in Spanish and Galician

(6)

86

87

88

89

90

91

92

93

94

95

96

97

98

99

100

101

$\begin{array}{ll}\text { Lara } & \text { unos ZAPAtos } \uparrow \\ \text { Iria } & \text { monísimos } \rightarrow \\ \text { Lara } & \text { pero carísimos } \rightarrow \\ & \text { catorce mil pesetas } \rightarrow \\ & \text { hija } \downarrow\end{array}$

Iria $\quad$ ARRE CArallo $\uparrow$

he he he

Lara catorce mil pesetas $\rightarrow<$ entre risas $>$

y digo yo $\rightarrow$

joder $\uparrow$

esos zapatos los compras $\rightarrow$

en cualquier SItio

incluso en el CORte

por la mitad de precio $\downarrow$

Gema es que (los comercios) pequeños $\rightarrow$

suelen ser los más caros $\downarrow$

In this extract, note that another participant, Iria, reacts to Lara's turn specifying the price of the shoes (lines 88-90), expressing astonishment by means of the Galician interjection arre carallo ('damn it', line 91) to support her friend's view that it was too high. As is shown in the following subsection, these data include some examples in which joder is also used for this purpose -to express surprise- as well as other emotive reactions.

\subsection{Expressing Minimal Emotional Assessments}

As noted in Section 2, Stenström (2006) attributes two discursive functions to taboo words in general: one phatic, serving to maintain contact between the speaker and the listener(s), and another non-phatic, which is oriented to communicate the speaker's feelings, the prototypical function of interjections (Drescher, 1997, p. 234). One example of the phatic function provided by Stenström (2006, p. 128) shows the use of joder as one participant's reaction to storytelling. In this case, joder constituted a turn by itself and expressed

Feminismo/s 38, July 2021, 53-83 
surprise, as we have just seen regarding arre carallo ('damn it') in extract (6). Extract (7) offers another similar example, in which joder is used for this purpose. As in (6), the participants are talking about clothes, and joder is employed as a reaction to the price of an item of clothing, indicated by the previous speaker (lines 1391-1393). In this case, the interjection is used by two participants in overlap. Also, note that it is produced with a marked elongation in the first vowel, which contributes to emphasising the meaning of this reaction as surprise:

Begoña eso hice yo con una chupa de cuero en el corte $\rightarrow$ ya le conté $\rightarrow$

1391 valía sesenta mil pelas $\rightarrow=$

$1392 \quad \rightarrow \quad(\mathrm{X}) \quad=[\mathrm{jo}:: \mathrm{der}] \rightarrow$

$1393 \quad \rightarrow \quad$ Silvia [jo::der] $\uparrow=$

1394

1395

Begoña $=$ pero era preciosa $\rightarrow$

y yo iba todos los días por allí a verla $\rightarrow$

In this example, the display of surprise by means of joder in response to the price previously indicated by Begoña implies that both participants consider it very high. This use could be included along with other forms such as anda ('come on') and vaya ('wow'), which are classified by Stenström (2014, pp. 80-81) as reactive markers 'showing surprise'.

However, there are examples in which joder is again used alone in response to a previous turn, displaying other emotive meanings. In extract (8), it is produced by Begoña (line 647) in reaction to a story told by Silvia about a woman who found a rose in her son's room. The woman thought it was a gift for her, but it was for the boy's girlfriend. Note that joder is also produced with a vowel elongation:

Silvia Y EL DOMINGO $\uparrow$

638 se va el chorvo con la rosa $\rightarrow$

639 para allí a dársela a la novia $\uparrow<$ riéndose $>$ $<$ risas> 
Gender and expletives as discourse markers: Some uses of joder in young women's interactions in Spanish and Galician

\begin{tabular}{|c|c|c|c|}
\hline 641 & & & en plan $\rightarrow$ \\
\hline 642 & & & $\{[a]$ ENTONCES ESA RO:SA $\uparrow$ \\
\hline 643 & & & NO ERA PARA Mí::\} $\rightarrow<$ lloriqueando $>$ \\
\hline 644 & & & $<$ risas $>$ \\
\hline 645 & & & dice que se llevó un cha:sco $\uparrow$ \\
\hline 646 & & & colega $\rightarrow$ \\
\hline 647 & $\rightarrow$ & Begoña & jode::r $\rightarrow$ \\
\hline 648 & & & he he he \\
\hline 649 & & Silvia & (xx) buscándolo $\uparrow$ \\
\hline 650 & & & además $\uparrow$ \\
\hline 651 & & & me hizo mucha gracia $\uparrow$ \\
\hline 652 & & & porque ya le andaba buscando un floreri::to $\rightarrow$ \\
\hline 653 & & & sabes? \\
\hline 654 & & Begoña & he he he \\
\hline 655 & & Silvia & pobriña $\rightarrow=$ \\
\hline 656 & $\rightarrow$ & Begoña & $=$ qué puta::da $\rightarrow$ \\
\hline 657 & & & $<1>$ \\
\hline
\end{tabular}

In this case, joder does not display surprise but a feeling of sadness or sorrow in reaction to the reported event, thus implying that the speaker considers it worthy of empathy. The same participant, Begoña, reinforces this evaluation later by saying qué putada ('It's a real bugger', line 656), with vowel elongation, in line with a previous expression of sympathy by Silvia: pobriña ('poor woman', line 655). In agreement with Drescher (1997, p. 238), I thus consider that uses of this kind generally constitute «more than a purely phatic feedback» and should be more globally accounted for as «emotional assessments or declarations of attitudes which are typical minor speaker contributions» (Drescher, 1997, p. 238).

\subsection{Correcting and Stalling}

While the uses of joder examined so far are mainly oriented to interpersonal goals or operate on both an interpersonal and a textual level, the 'correcting' and 'stalling' functions to be addressed here are purely discourse

Feminismo/s 38, July 2021, 53-83 
oriented. These uses have been found to be frequent in the talk of a same speaker -here, Eva- especially with respect to the stalling function, as shown in extract (3). The correcting function was identified in extract (9), which provides an excellent example of how joder can be used like the marker $o$ sea ('that is') to introduce a reformulation or self-repair (on the correcting function of o sea, see Cortés, 1991, pp. 59-60; Stenström, 2014, p. 86). Eva is trying to describe the personality of her male friend and partially repeats a self-repair to correct her use of raro ('odd man'), replacing it with difícil ('difficult man'). The first self-repair is introduced by o sea ('that is'), while the next one is preceded by joder (lines 521-527):

(9)

$\begin{array}{llll}514 & & \text { Eva } & \text { (es más) } \\ 515 & & & \text { me dijo } \rightarrow \\ 516 & & \text { yo soy } \\ 517 & & <1> \\ 518 & & & \text { soy raro } \downarrow \\ 519 & & \text { Cris } \quad & \text { raro }= \\ 520 & & \text { Eva } & \text { r raro sabes? } \\ 521 & \rightarrow & & \text { o sea } \\ 522 & \rightarrow & & \text { raro } \uparrow \\ 523 & \rightarrow & & \text { no } \rightarrow \\ 524 & \rightarrow & & \text { difí:cil } \rightarrow \\ 525 & \rightarrow & & \text { joder } \\ 526 & \rightarrow & & \text { no es que sea raro } \rightarrow \\ 527 & \rightarrow & & \text { es que es difícil } \downarrow \\ 528 & & & \text { y muchas veces } \uparrow \\ 529 & & & \text { pues se ago:bia } \uparrow\end{array}$

As previously explained, the use of discourse markers on a textual level as stalling devices (Stenström, 2014) or fillers (Cortés, 1991) means that they serve «to gain time and think of what to say next» (Stenström, 2014, p. 92), often when the speaker is hesitating. Cortés (1991, p. 29) also argues that if a filler is often used by the same speaker, it would constitute a muletilla 
Gender and expletives as discourse markers: Some uses of joder in young women's interactions in Spanish and Galician

('pet word' or 'tag'). This seems to be the case for Eva. For example, extract (10) shows that this participant uses joder twice in this way, while talking about the dialogue she had with her intimate male friend about the future of their relationship:

(10)

773 Eva él desde un principio me dijo $\rightarrow$

774

775

Cris sí

776

777

778

779

780

781

782

783

784

785

786

787

788

789

790

791

792

793

794

795

796

797

798

lo que había $=$

Eva = lo que ha:y $\uparrow$

o sea $\rightarrow$

si lo quieres bien $\uparrow$

y si no lo quieres $\uparrow$

no lo quieres $\rightarrow$

pero yo $\uparrow$

$<0.5>$

Cris quiero eso $\rightarrow$

sí =

Eva $\quad=$ quiero esto $\rightarrow$

y yo no voy a estar con una tía $\uparrow$

más de::

$\{[p]$ porque me (entró) ayer $\} \rightarrow$

y joder

sabes?

y él

y así hablando con é:l $\rightarrow$

y tal $\uparrow$

$<0.5>$

eso $\rightarrow$

de rollos $\uparrow$

Feminismo/s 38, July 2021, 53-83 


$\begin{array}{lll}799 & \rightarrow & \text { que } \\ 800 & \rightarrow & \text { que joder } \rightarrow \\ 801 & \rightarrow & \text { que guay } \uparrow\end{array}$

In this extract, Eva is replaying what her male friend told her about the relationship between them and what he expected of it (lines 773, 777-782, 786-789), suggesting that such a relationship could not be very long (lines 786-789). The reporting is interrupted by the speaker, as she leaves the utterances unfinished, turning to comment on the moment the conversation had been maintained (lines 787-790). This parenthetical comment is contextualised by a prosodic change, as it is produced with a piano voice (line 790). In the following turns, the speaker's expressive hesitations become more noticeable, as there are repetitions of the connector $y$, but new information is not added (lines 791-795). The first use of $y$ ('and') is followed by joder (line 791) as a filler, and then sabes? is produced as a contact marker to invite listeners' cooperation (Briz, 1998, p. 224f.; Stenström, 2014, p. 72), reinforcing the speaker's expressive difficulties. After a micropause (line 796), Eva summarises what the boy described as an informal relationship, employing the noun rollos ('flings', lines 797-798) and again hesitates in evaluating this, making repetitions and using joder once more as a filler (lines 799-801).

According to Coates (1996), women frequently use different forms that serve as hedges in all-female interactions because they often talk about very personal and sensitive topics, while the same forms can also be interpreted as stalling devices because of the difficulties in talking about such issues (see also Stenström, 2014, p. 92). The sensitive topic that is talked about in this interaction can also explain the frequent use of joder as a filler by Eva, while it seems unlikely that this expletive could also be employed as a hedge.

\section{CONCLUSIONS}

The analysis given in this paper demonstrates that joder has developed multiple functions in interaction that are derived and/or linked to its primary use as a 'vulgar' interjection to express the speaker's feelings. This way of developing multifunctionality is characteristic of discourse markers (Blas Arroyo, 1995, p. 87), a pragmatic category in which joder also should be included.

Feminismo/s 38, July 2021, 53-83 
Thus, this study provides empirical support for arguments in favour of considering interjections as possible discourse markers in contrast to assumptions that these kinds of words only fulfil communicative functions to which they correspond in accordance with their grammatical category, such as the expression of the speaker's feelings. This assumption seems to be an important reason why research on expletives has generally used quantitative methods. In contrast to this, I conclude that claims concerning the functions of expletives and interjections in general should be based on empirical study and not on their grammatical categorisation. Furthermore, such empirical research should include more discourse-analytical approaches since these are precisely the ones that allow us to observe in detail the possibly different ways in which they are used in interactions.

From a gender viewpoint, the analysis suggests that joder can also be attributed a sociolinguistic function as a marker of 'young femininities', as it has illuminated how this expletive is integrated into young women's speaking style in contrast to gender-based traditional rules and broader characterisations of 'women's talk' in Language and Gender research. If we also consider quantitatively oriented studies on female teenagers from London and Madrid (Stenström, 2006), the use of this expletive as a discourse marker provides a key to explaining its similar frequency to the use of fuck in English, which is much more grammatically variable. Also, it can explain that gender differences in the use of these words are diminishing in terms of frequency of use between girls and boys, according to Stenström (2014, p. 11). Future research should explore this apparent process of diminishing gender differences in other geographical areas as well as the possible explanations for it. In the following, I raise several hypotheses related to this.

On the one hand, we can hypothesise that young females are, to some extent from a gender perspective, consciously triggering a sociolinguistic change in the use of expletives and taboo words by making regular use of them, apparently the least 'strong' words, to symbolise or to claim equality with boys. This is in line with suggestions made by other researchers (López García \& Morant, 1991). Such a process can be related to the fact that in Spain, as in other countries and societies, people are becoming aware and critical of gender constructions, as gender equality has been playing an increasingly prominent role in recent decades in the political agenda and

Feminismo/s 38, July 2021, 53-83 
the media. On the other hand, we can also hypothesise that such a challenge is limited to the life stage of the speakers. After all, young women's actions against conventional ideas of femininity are not new, but they have been around for centuries, as Nakamura (2014) demonstrates in her historical discourse analysis of 'schoolgirl speech' in Japan at the end of 1880s.

Generally, the use of taboo words by young speakers is interpreted as «a means to provoke the older generation and to oppose authority» (Stenström, 2006, p. 124; see also Stenström, 2014). However, it should also be remarked that girls, in contrast to boys, are not only challenging adult norms but also traditional rules on femininity. Pichler (2015) reviews recent ethnographic studies on young women's displays of verbal toughness, noting that «there does not appear to be a consensus about the extent to which this toughness ultimately empowers the girls» (Pichler, 2015, p. 198), as some of them opt for changing their speaking styles over the years because of new personal and professional situations. If rebellious performances of this type are not beneficial for them in the long term, young women's challenges to gender norms by using expletives and taboo words would lose strength as they grow older, and thus this phenomenon could be limited to this youthful stage.

Lastly, we should also consider, following Murphy (2009), the influence of music, film and television, which «have pushed the boundaries of expletive use, where a word like FUCK, which was once considered taboo, is now being regarded as commonplace» $(2009$, p. 87). From this perspective, young women's use of joder and other expletives could be, if only partially, a reflection of these processes, while young men could continue to underline gender differences in talk by selecting and focusing on those forms that are still severely stigmatised. Research on the use of expletives could delve into gender issues by exploring these possibilities, employing different quantitative and qualitative research methods.

\section{REFERENCES}

Acuña, V. (2002-2003). Gendered emotive displays in complaint discourse. In F. Ramallo \& M. Fernández (Eds.), Sociolinguistics in Galicia: Views on diversity, a diversity of views [Monograph]. Estudios de Sociolingüistica, 3(2), 139-172. https://doi.org/10.1558/sols.v3i2.i

Feminismo/s 38, July 2021, 53-83 
Gender and expletives as discourse markers: Some uses of joder in young women's interactions in Spanish and Galician

Acuña, V. (2004). Complaint stories in male contexts: the power of emotions. Spanish in Context, 1(2), 181-213. https://doi.org/10.1075/sic.1.2.03acu

Acuña, V. (2009). Género y discurso. Las mujeres y los hombres en la interacción conversacional. Lincom.

Acuña, V. (2011a). La realización de quejas en la conversación femenina y masculina. Lincom.

Acuña, V. (2011b). Recursos prosódicos y verbales para la intensificación de las emociones en la interacción conversacional cotidiana: ejemplos de su utilización en actividades de queja. Oralia, 14, 254-291.

Acuña, V. (2012). The humorous display of transgressor feminities: 'sharing a laugh' in Spanish/Galician friendly talk among young women. Sociolinguistic Studies, 6(1), 121-147. https://doi.org/10.1558/sols.v6i1.121

Acuña, V. (2017a). La realización de feminidad entre jóvenes veinteañeras: el papel de las confidencias sobre las relaciones con los hombres en la conversación juvenil femenina. Estudios Filológicos, 59, 7-30. https://doi.org/10.4067/ S0071-17132017000100001

Acuña, V. (2017b). Conversación juvenil e identidad de género: despliegues de feminidad heterosexual en grupos de jóvenes veinteañeras. Círculo de Lingüistica Aplicada a la Comunicación, 69, 3-33. https://doi.org/10.5209/ CLAC. 55312

Acuña, V. (2020). Staging mental discursive processes and reactions: The construction of direct reported thought (DRT) in conversational storytelling. Language in Society, published online: 16 March 2020. https://doi.org/10.1017/ S0047404520000020

Albelda, M., Cestero, A. M., Guerrero, S., \& Samper, M. (2020). Variación sociopragmática y geolectal en el uso de atenuación. Lengua y Habla, 24, 1-53.

Álvarez Cáccamo, C. (1990). The Institutionalization of Galician: Linguistic Practices, Power, and Ideology in Public Discourse [Unpublished doctoral dissertation]. University of California at Berkeley.

Aries, E. (1996). Men and women in interaction. Reconsidering the differences. Oxford University Press.

Bailey, L. A., \& Timm, L. A. (1976). More on women's and men's expletives. Anthropological Linguistics, 18, 438-449.

Blas Arroyo, J. L. (1995). La interjección como marcador discursivo: el caso de eh. Anuario de Lingüística Hispánica, 11, 81-118. 
Gender and expletives as discourse markers: Some uses of joder in young women's interactions in Spanish and Galician

Borreguero Zuloaga, M. (2015). A vueltas con los marcadores discursivos: de nuevo sobre su definición y sus funciones. In A. Ferrari, L. Lala, \& R. Stojme-Nova (Eds.), Testualità. Fondamenti, unità, relazioni / Textualité. Fondements, unités, relations / Textualidad. Fundamentos, unidades, relaciones (pp. 151-170). Cesati.

Briz, A. (1998). El español coloquial en la conversación. Esbozo de pragmagramática. Ariel.

Briz, A., Pons, S., \& Portolés, J. (Eds.) (2008). Diccionario de partículas discursivas del español. www.dpde.es.

Brown, P., \& Levinson, S. (1987). Politeness. Some universals of language use. Cambridge University Press. https://doi.org/10.1017/CBO9780511813085

Cameron, D., McAlinden, F., \& O'Leary, K. (1988). Lakoff in context: The social and linguistic functions of tag questions. In J. Coates, \& D. Cameron (Eds.), Women in their speech communities. New perspectives on language and sex (pp. 74-93). Longman.

Chun, S. K. (1991). La utilización de los tacos: factor sexo y nivel sociocultural. Unpublished manuscript. Universidad Complutense.

Clark, H., \& Gerrig, R. (1990). Quotations as demonstrations. Language, 66, 764-805. https://doi.org/10.2307/414729

Coates, J. (1996). Women talk. Conversation between women friends. Blackwell.

Coates, J. (2003). Men talk. Stories in the making of masculinities. Blackwell. https://doi.org/10.1002/9780470755617

Coates, J. (2004). Women, men and language ( $3^{\text {rd }}$ ed.). Routledge.

Cortés, L. (1991). Sobre conectores, expletivos y muletillas en el español hablado. Ágora.

De Klerk, V. (1992). Hot taboo are taboo words for girls? Language in Society, 21, 277-289. https://doi.org/10.1017/S0047404500015293

De Klerk, V. (1997). The role of expletives in the construction of masculinity. In S. Johnson, \& U.H. Meinhof (Eds.), Language and masculinity (pp. 144158). Blackwell.

De Latte, F., \& Enghels, R. (2019). La variación lingüística del vocativo en el lenguaje juvenil madrileño. Revue Romane, available online 11 September, 1-19. https://doi.org/10.1075/rro.18011.del

Drescher, M. (1997). French interjections and their use in discourse. In S. Niemeier, \& R. Dirven (Eds.), The language of emotions. Conceptualisation, 
Gender and expletives as discourse markers: Some uses of joder in young women's interactions in Spanish and Galician

expression, and theoretical foundation (pp. 233-246). John Benjamins. https:// doi.org/10.1075/z.85.18dre

Edeso Natalías, V. (2005). Usos discursivos del vocativo en español. Español actual: Revista de español vivo, 84, 123-142.

Goffman, E. (1967). Interaction ritual: Essays in face-to-face behavior. Aldine Transaction.

Holmes, J. (1995). Women, men and politeness. Longman.

Holmes, J., \& King, B. W. (2017). In A. Barron, Y. Gu, \& G. Steen (Eds.), The Routledge handbook of pragmatics. Routledge. https://doi.org/10.4324/9781315668925

Hughes, S. E. (1992). Expletives of lower working-class women. Language in Society, 21, 291-303. https://doi.org/10.1017/S004740450001530X

Jespersen, O. (1922). Language: Its nature, development and origin. Allen \& Unwin. Labov, W. (1972). Language in the inner city. University of Pennsylvania Press.

Lakoff, R. (2004). Language and woman's place. In M. Bucholtz (Ed.), Language and woman's place. Text and commentaries. Oxford University Press. (Original work published 1975).

López García, Á., \& Morant, R. (1991). Gramática femenina. Cátedra.

Lozano Domingo, I. (1995). Lenguaje femenino, lenguaje masculino. ¿Condiciona nuestro sexo la forma de hablar? Minerva.

Martínez Lara, J. A. (2009). Los insultos y las palabras tabúes en las interacciones juveniles. Un estudio sociopragmático funcional. Boletín de Lingüistica, 21(31), 59-85.

Mills, S. (2003). Gender and politeness. Cambridge University Press. https://doi. org/10.1017/CBO9780511615238

Murphy, B. (2009). 'She's a fucking ticket': The pragmatics of FUCK in Irish English-an age and gender perspective. Corpora, 4(1), 85-106. https://doi. org/10.3366/E1749503209000239

Nakamura, M. (2014). Gender, language and ideology: A genealogy of Japanese women's language. John Benjamins. https://doi.org/10.1075/dapsac.58

Ochs, E., \& Schieffelin, B. (1989). Language has a heart. Text, 9(1), 7-25. https:// doi.org/10.1515/text.1.1989.9.1.7

Oliver, M. M., \& Rubin, J. (1975). The use of expletives by some American women. Anthropological Linguistics, 17, 191-197.

Padilla Cruz, M. (2019). On the pragmatic and conversational features of venting: A reply to Thorson and Baker. Social Epistemology Review and Reply Collective, 8(2), 21-30.

Feminismo/s 38, July 2021, 53-83 
Gender and expletives as discourse markers: Some uses of joder in young women's interactions in Spanish and Galician

Pichler, P. (2015). Language, gender and identity. In N. Bonvillain (Ed.), The Routledge handbook of linguistic anthropology (pp. 191-205). Routledge. https://doi.org/10.4324/9780203492741-22

Pomerantz, A. (1984). Agreeing and disagreeing with assessments: Some features of preferred/dispreferred turn shapes. In J. Maxwell Atkinson \& J. Heritage (Eds.), Structures of social action: Studies in conversation analysis (pp. 57-101). Cambridge University Press. https://doi.org/10.1017/ CBO9780511665868.008

Pujolar, J. (1997). Masculinities in a multilingual setting. In S. Johnson, \& U. H. Meinhof (Eds.), Language and masculinity (pp. 86-106). Blackwell.

RAE, \& ASALE (2010). Nueva gramática de la lengua española. Manual. Espasa Calpe.

RAE, \& ASALE (2014). Diccionario de la lengua española (23. a ed.). Espasa Calpe. https://www.rae.es/

Rodríguez Yáñez, X. P. (2007). Paradigmes pour l'étude sociolinguistique du bilinguisme. In J. M. Eloy \& T. Ó. hIfearnáin (Eds.), Langues proches-Langues collatérales. Near languages-Collateral languages (pp. 37-62). L'Harmattan.

Rodríguez Yáñez, X. P., \& Casares, H. (2002-2003). The Corpus of Galician / Spanish Bilingual Speech of the University of Vigo: Codes tagging and automatic annotation. Estudios de Sociolingüistica, 4(1), 358-382. https://doi. org/10.1558/sols.v4i1.358

Ronald, C., \& McCarthy, M. (2006). Cambridge grammar of English. Cambridge University Press.

Staley, C. M. (1978). Male-female use of expletives: A heck of difference in expectations. Anthropological Linguistics, 20, 367-377.

Stenström, A. B. (2006). Taboo words in teenage talk. London and Madrid girls' conversations compared. In C. Mar-Molinero, \& M. Stewart (Eds.), Language variation and change: Historical and contemporary perspectives [Monograph]. Spanish in Context, 3(1), 115-138. https://doi.org/10.1075/ sic.3.1.08ste

Stenström, A. B. (2014). Teenage talk. From general characteristics to the use of pragmatic markers in a contrastive perspective. Palgrave Macmillan. https:// doi.org/10.1057/9781137430380

Stenström, A. B., Andersen, G., \& Hasund, I. K. (2002). Trends in teenage talk. Corpus compilation, analysis and findings. John Benjamins. https://doi. org/10.1075/scl.8 
Gender and expletives as discourse markers: Some uses of joder in young women's interactions in Spanish and Galician

Trudgill, P. (1983). On dialect: social and geographical perspectives. Blackwell. Tusón, A. (1997). El análisis de la conversación. Ariel.

Zimmermann, K. (2002). La variedad juvenil y la interacción verbal entre jóvenes. In F. Rodríguez (Ed.), El lenguaje de los jóvenes (pp. 137-163). Ariel. Zimmermann, K. (2005). Construcción de la identidad y anticortesía verbal. Estudio de conversaciones entre jóvenes masculinos. In D. Bravo (Ed.), Estudios de la (des)cortesía en español. Categorías conceptuales y aplicaciones a corpora orales y escritos (pp. 245-271). Dunken.

\section{APPENDIX: TRANSCRIPTION CONVENTIONS}

$\begin{array}{ll}\text { Rounded print } & \text { Spanish } \\ \text { Bold print } & \text { Galician } \\ \text { Line of transcription } & \text { Intonational phrase } \\ \uparrow & \text { Rising intonation phrase-final } \\ \downarrow & \text { Falling intonation phrase-final } \\ \rightarrow & \text { Sustained intonation phrase-final } \\ ? & \text { Interrogative intonation } \\ . . & \text { Pause shorter than one second } \\ <3> & \text { Pause of indicated length (in seconds) } \\ \text { (entró) } & \text { Uncertain transcription } \\ \text { (X) } & \text { Uncertain participant } \\ \text { (xx) } & \text { Unintelligible segment } \\ \text { pero:: } & \text { Lengthened sound } \\ \text { pregu- } & \text { Truncated sound } \\ \text { Ana: qué va } \rightarrow= & \\ \text { Begoña: }=\text { no creo } \downarrow= & \text { No interval between turns } \\ & \\ \text { (X): }=\text { bueno [hombre] } \uparrow & \text { Conversational overlap } \\ \text { Sofía: [NO NADA] } \rightarrow & \end{array}$

Feminismo/s 38, July 2021, 53-83 
Gender and expletives as discourse markers: Some uses of joder in young women's interactions in Spanish and Galician

CAPITALS
\{\}
$\{[\mathrm{p}]\}$
$\{[\mathrm{ac}]\}$
$\{[\mathrm{dc}]\}$
$\{[\mathrm{a}]\}$
$<$ riéndose>

fortis volume

Segment affected by a phenomenon

piano volume

Accelerated tempo

Decelerated tempo

Higher pitch

Additional comments

Feminismo/s 38, July 2021, 53-83 